\title{
Research on the Status, Trend and Strategy of Chinese Free Trade Zone Construction
}

\author{
Xinke $\mathrm{Wu}^{1}$ \\ ${ }^{1}$ Nanyang Institute of Technology, Nanyang, Henan, 473004
}

Keywords: free trade zone; develop trend; develop strategy

\begin{abstract}
In order to comply with the evolution of international economic and trade rules and respond to pressures at home and abroad, China has accelerated the implementation of the free trade zone strategy. Compared to the traditional free trade area (FTA), the Free Trade Zone (FTZ) established by China in the "overseas customs and territory" aims to actively explore the governmental functions, investment and trade management innovation model, and expand the opening of the service industry. On the basis of elaborating the evolution of the free trade zone, this paper clarifies the development of our country from the reform and opening-up of the special economic zone to the free trade zone in "new normal”, and make a horizontal comparison of the current status of Chinese four major free trade zones. The formation of replicable and scalable experience has enabled it to develop into a "practical field" for promoting reforms and improving the level of open economy, playing a demonstration role and expanding new space for economic growth.
\end{abstract}

\section{Introduction}

With the emergence of new trends in the development of international trade and investment, the limitations of the World Trade Organization's multilateral trading system have become increasingly prominent. Coupled with the pressure of domestic economic restructuring, Chinese long-term dependence on foreign trade to stimulate economic growth has been unable to adapt to the requirements of the new era. The 17th National Party Congress raised the construction of the free trade zone into a national strategy. The 18th Party Congress also proposed to speed up the implementation of the free trade zone strategy. The Third Plenary Session of the 18th CPC Central Committee also pointed out that it is necessary to form a global network of high-standard free trade zones [1]. So far, China has signed 14 free trade agreements involving 22 countries and regions. Among them, there are 12 FTAs that have signed agreements with countries such as Australia, South Korea, Switzerland, Iceland, Costa Rica, Peru, Singapore, New Zealand, Chile, Pakistan, and ASEAN (Data from the China Free Trade Zone Service Network). There are four free trade zones under study. In addition, China established the China (Shanghai) Free Trade Zone (FTZ) in September 2013 and the second batch of China (Shanghai) Free Trade Zone in Tianjin, Guangdong and Fujian in April 2015. As the first batch of China-based foreign trade zones, the Shanghai Free Trade Zone has clearly stated the overall requirements and major tasks and measures in the "Overall Plan for the China (Shanghai) Free Trade Pilot Zone”. Areas of openness, transformation of trade development methods, opening up of innovation in the financial sector, and protection of the legal system have all been standardized to expand the new space for economic growth and create an "upgraded version" of the Chinese economy [2]. From the perspective of historical evolution, it is of theoretical and practical significance to examine the vertical development of the "predecessor" of Chinese free trade trial zone-the special economic zone-and to use this as a basis for the horizontal comparison of the existing four free trade zones in China.

\section{Analysis of the Development Status of China Free Trade Zone}

Since the 21st century, the construction of Chinese free trade zone has achieved remarkable results. The construction of the free trade zone has greatly enhanced the level of Chinese opening to 
the outside world, which has enabled Chinese economic and trade relations with the free trade zone to continue to advance and the economic integration and exchanges have been continuously enhanced. At the same time, it has promoted the rapid development of Chinese manufacturing industry, adjustment of agricultural restructuring, and competitiveness of service industries. Enhancements.

According to the service network of the Ministry of Commerce of the People's Republic of China (see Table 1), China is currently constructing 19 free trade zones, involving 32 countries and regions. Among them, 14 have signed the Free Trade Agreement, involving 22 countries and regions, namely, China and ASEAN, Singapore, Pakistan, New Zealand, Chile, Peru, Costa Rica, Iceland, Switzerland, South Korea and Australia, the FTA, the Mainland and Hong Kong. The Closer Economic Partnership Arrangement (CEPA) between Macao and the Mainland and Taiwan, and the Cross-Strait Economic Cooperation Framework Agreement (ECFA) between the Taiwan Strait and the Taiwan Strait. At present, the free trade agreements between South Korea and Australia have all been implemented; seventeen free trade agreements are being negotiated, involving 22 The countries are the FTAs between China and the Gulf Cooperation Council (GCC), Sri Lanka and Norway, the China-Japan-ROK FTA, the RCEP and the China-ASEAN Free Trade Agreement (" $10+1$ ") negotiations, and China-Pakistan The second phase of the trade agreement. In addition, China has completed a joint research with India's Regional Trade Arrangement (RTA); it is conducting a joint feasibility study with the Colombian Free Trade Zone; it has also joined the Asia-Pacific Trade Agreement. Among them, on June 17, 2015, the signing of the remarkable China-Australia FTA was the first high-level free trade agreement between China and Western developed countries [3]. Australia became the first trading partner to make an open commitment to Chinese service trade with the "negative list" management approach. China still promises to open its service sector to Australia with a positive list. At the same time, the China-Australia Free Trade Area Agreement has a major breakthrough in the personnel exchanges between the two sides. Through the "Work Holiday Visa Arrangement", Australia provides Chinese youths with a holiday work visa of 5,000 people per year in Australia, and also offers professional staff with Chinese characteristics (Chinese medicine practitioners, Chinese). Teachers, Chinese chefs and martial arts coaches provide 1,800 annual entry quotas. In the investment field, Australia has significantly reduced the threshold of Chinese investment review in Australia. The standard for investment exemption has been adjusted from $\mathrm{A} \$ 248$ million to $\mathrm{A} \$ 1.078$ billion.

\section{The Main Issues in the Development of Chinese Free Trade Zone}

The construction of the free trade zone needs a long process of negotiation and promotion, and it cannot be accomplished overnight. Judging from the current results of the implementation of the China Free Trade Zone strategy, only 12 of the specific implementation have been completed. The substantive negotiations between China, South Korea and China and Australia have ended, but it will take some time before they can formally enter into force. Moreover, most trading partners are developing countries, which may be related to Chinese internal drive to release economic production capacity. However, based on long-term considerations, the establishment of high-level free trade zones with developed countries can enhance the level of economic development. In the top ten countries or regions in the World Economic Forum's National Competitiveness Index (2014-2015), the only partner who has established a free trade zone with China is Hong Kong, China, and the other nine are dissociated from the territory of the China Free Trade Zone. In addition, the establishment of bilateral free trade zones in the near future is more difficult in the short term. Given various reasons, negotiations between China and the United States, Japan, and Europe in the three major poles of growth in the free trade zone are still fraught with difficulties. Obviously, good partnerships with developed countries have a direct impact on Chinese opening up to the outside world and the absorption of dividends [4].

The establishment of a free trade zone is the result of the dual role of politics and economy. The establishment of free trade zones with most countries is mainly due to differences in economic interests. From the outset, the construction of Chinese free trade zone has taken the political need to 
adjust the relationship between the country and the country as an important starting point. District negotiations often even exceed economic interests. According to import and export data, in the East Asian regional integration, Chinese economic interests are the highest among China, Japan and South Korea and the ASEAN, followed by the China, Japan and South Korea FTAs; once again China and Japan FTAs, and finally China and ASEAN. The level of economic development in the ASEAN region is relatively low, and it is similar to the industrial structure of China. Therefore, the possibility of China obtaining economic benefits from it is limited in the short term. Closer economic and trade relations arrangements with Hong Kong and Macao are more of a politically-driven strategy that uses Mainland China to promote the prosperity of the Hong Kong and Macao economy.

\section{Strategic Thinking on Development of China Free Trade Zone}

China is one of the biggest beneficiaries of the last round of globalization, but the situation is changing. A new round of globalization China will replace the import and export of general trade with the internationalization of the renminbi, that is, importing engineering, services, commodities, capital, and currencies into the Asia-Pacific and other emerging market regions under the escort of huge foreign exchange reserves to make foreign exchange more efficient. Invest and participate in global currency competition. Based on these new rounds of opening up to the outside world, China is shifting from "keeping a low light to raising a bright future" to "make a difference." Logically, the process from trade to investment to currency is a progressive process. By deepening cross-border economic ties with trade, exporting surplus production capacity and capital through investment, and grafting the RMB internationalization strategy in these two processes, the impact of Chinese economy will eventually increase with the internationalization of RMB. The Free Trade Zone and the "One Belt and One Road" are the implementation strategies under this background. The decision-making layer proposes to speed up the implementation of the free trade zone strategy, and gradually establish a free trade zone network that is close to the periphery and radiates the "One Belt and One Road" and faces the world. With the "Belt and Road" countries and regions along the route to build commercial and trade zones. China has 14 land-contributing countries and 28 countries facing each other across the sea. It is the country with the largest number of land and sea neighbors in the world. On March 28, 2015, the National Development and Reform Commission, the Ministry of Foreign Affairs, and the Ministry of Commerce jointly issued the "Vision and Action for Promoting the Joint Construction of the Silk Road Economic Belt and the 21st Century Maritime Silk Road”. The "One Belt and One Road” runs through Asia, Europe and Africa, with an active East Asian economic circle and an advanced European economic circle. The middle hinterland countries have huge potential for economic development. The Silk Road Economic Belt focuses on China Central Asia, Russia, and Europe (the Baltic Sea); China passes through Central Asia, West Asia to the Persian Gulf, and the Mediterranean Sea; China goes to Southeast Asia, South Asia, and the Indian Ocean. The key directions of the 21st Century Maritime Silk Road are from Chinese coastal ports over the South China Sea to the Indian Ocean, extending to Europe; from Chinese coastal ports to the South Pacific to the South Pacific. The strategy of opening up to the simpler and more decentralized reforms is a new round of high-level tests of opening up and a wider range of reforms, which will further increase the level of Chinese open economy. From a strategic perspective, the "One Belt and One Road" and the free trade zone are the same tactical systems. Through the "Belt and Road" initiative, the meridians constructed in the Free Trade Zone will increase political mutual trust on the basis of economic co-prosperity and lay the foundation for bilateral and multilateral trade negotiations [5].

The advancement and trend of TPP are important international economic and trade activities that China cannot avoid. According to customs statistics in 2010, bilateral trade between China and TPP members accounted for $22.8 \%$ of total foreign trade. If Japan joins TPP, this proportion will rise to $32.8 \%$. As the United States joins and dominates, TPP negotiations have doubled in weight due to the support of the world's largest country. In view of the TPP process, the country is broadly divided into two groups. One is that the United States intends to contain China through economic means, 
gain an opportunity to build a new Asian order, or be concerned about the fragility of relevant domestic industries, or be based on national strategic security. For other reasons, it is believed that China should adopt a kind of protest or wait-and-see attitude towards the TPP. Another view is that further opening up is the trend of the times and opening up of the service industry has become the focus of globalization in the next phase. China should increase its right to speak as soon as possible and use TPP's high standards to achieve a qualitative improvement and baptism of domestic industries. The standards put forward by the United States in the TPP negotiations go far beyond the level of Chinese previous foreign commitments in the FTA, but in the long run, many of these standards are in line with the development direction of Chinese future industries. In the China-Japan-Korea Free Trade Area and the RCEP negotiations, some negotiators who also participated in the TPP have also submitted to China a higher free trade agreement standard. Therefore, China needs to design standards that meet the overall and long-term interests of China in advance as a preplan, and promote the formation of a free trade agreement rule system that is conducive to Chinese industrial development.

\section{Conclusion}

With the development of the productivity of all countries in the world, the international division of labor is deepening, and the degree of interdependence of the global economy has been unprecedentedly increased. The expansion of capital objectively requires breaking the geographical limitations of the country's borders, increasing the efficiency of transnational allocation of resources, harmonizing market rules, and adopting joint regulation of macroeconomic fluctuations, in order to promote the steady and steady development of the world economy. Most countries or regions in the world have participated in negotiations and established various regional economic integration and cooperation. As the world's second largest economy, China cannot be alone, and it is even necessary to act as the main promoter to develop free trade in line with national strategies. District pattern. The implementation of the Free Trade Area (FTA) strategy plays an important role in promoting the rapid development of trade and investment between China and trading partners, promoting domestic industrial restructuring and economic growth, and strengthening the economic cooperation relationship between regional members for mutual benefit and win-win results. The positive attitude of Chinese peaceful development and opening to the outside world has made important contributions to winning Chinese discourse power and influence in regional and international affairs and creating a good external environment.

\section{References}

[1] Zhong Jian, Luo Haiping. The Native Market, Transition Market, and Special Economic Zones--Also on the Nature of Special Economic Zones [J]. Open Herald, 2009, (1).

[2] Xu Xianxiang, Chen Xiaofei. Special Economic Zone: The Starting Point of Chinese Gradual Reform [J]. World Economic Papers, 2008, (1).

[3] Luo Qinghe, Xu Xinhua. The Transformation of Special Economic Zones and the Study of Chinese Patterns [J]. Chinese Special Economic Zones, 2014, (1).

[4] Luo Qinghe, Pan Daoyuan. Study on the Functional Orientation of Special Economic Zone during the Transition Period [J]. Reform and Strategy, 2015, (9).

[5] Wang Tao, Fan Wenqiang. Tianjin, Guangdong, Fujian, Leading Free Trade Zone 2.0 [J]. China Ocean Shipping, 2015, (1). 